\title{
Effect of rennet on the composition, proteolysis and microstructure of reduced-fat Cheddar cheese during ripening
}

\author{
Kevany Soodam ${ }^{1,2}$ - Lydia Ong ${ }^{1,2,4}$ - Ian B. Powell ${ }^{3}$ • \\ Sandra E. Kentish ${ }^{1,4}$ - Sally L. Gras ${ }^{1,2,4}$
}

Received: 30 January 2015 / Revised: 21 July 2015 / Accepted: 23 July 2015 /

Published online: 18 August 2015

C) INRA and Springer-Verlag France 2015

\begin{abstract}
Rennet is an important ingredient in Cheddar cheese manufacturing and both the type used and the concentration applied can affect the ripening process. In this work, reduced-fat Cheddar cheese was produced using different concentrations of microbial rennet (Hannilase; 0.026, 0.052 and 0.150 international milk clotting units (IMCU). $\mathrm{g}^{-1}$ of milk) as well as recombinant camel chymosin (0.052 IMCU.g ${ }^{-1}$ of milk). The composition of the resulting cheeses was not statistically different, but the ratio of $\mathrm{pH} 4.6$ soluble nitrogen/total nitrogen ( $\mathrm{pH}$ 4.6-SN/TN) increased significantly with increasing Hannilase rennet concentration. This ratio was also significantly lower in the cheese made with recombinant camel chymosin at a similar rennet concentration. Microstructural, biochemical and textural changes in the cheese were also monitored during ripening. The gel made with a high rennet concentration was qualitatively more porous but these changes in porosity were not reflected in the freshly pressed cheese. After 31 weeks of ripening, the cheese made with recombinant camel chymosin had a thicker protein network compared to the cheese made with microbial rennet (Hannilase), possibly due to lower proteolysis. Most of the Hannilase rennet was lost to the whey when the rennet was increased above the concentration of 0.052 IMCU.g ${ }^{-1}$ of milk. A lower concentration of Hannilase rennet may prove beneficial,
\end{abstract}

This paper is part of the Special issue dedicated to the 9th International Cheese Symposium held in Cork, Ireland and organized by Teagasc in collaboration with University College Cork and INRA, 12th \& 13th November 2014.

Sally L. Gras

sgras@unimelb.edu.au

1 Department of Chemical and Biomolecular Engineering, The University of Melbourne, Parkville, VIC 3010, Australia

2 Bio21 Molecular Science and Biotechnology Institute, The University of Melbourne, Parkville, VIC 3010, Australia

3 Dairy Innovation Australia Limited, 180 Princes Highway, Werribee, VIC 3030, Australia

4 ARC Dairy Innovation Hub, Department of Chemical and Biomolecular Engineering, The University of Melbourne, Parkville, VIC 3010, Australia 
as the texture was not significantly affected at the end of the observed ripening period. Recombinant camel chymosin may potentially be used as a substitute for products requiring lower proteolysis during ripening. However, the texture of this cheese was harder than the cheese made with Hannilase rennet at the end of the ripening period.

Keywords Cheddar cheese $\cdot$ Ripening $\cdot$ Cheese microstructure $\cdot$ Microbial rennet $\cdot$ Camel chymosin $\cdot$ Proteolysis

\section{Introduction}

The term rennet is used to describe the wide range of coagulants that can be used for the coagulation of milk into a gel structure. Bovine calf rennet, which consists primarily of chymosin, has traditionally been used in cheese making, but a growing cheese industry, combined with a limited supply of calf rennet, has led to the search for calf rennet substitutes (Sousa et al. 2001). Rennet can originate from other animal sources (e.g. porcine pepsin, bovine pepsin and chicken pepsin), microbial sources (e.g. Rhizomucor (Mucor) miehei, Rhizomucor pusillus and Cryphonectria (Endothia) parasitica) or plant sources (e.g. Cynara cardunculus) (Sousa et al. 2001). Inserting the coding sequence for bovine chymosin into microorganisms has made fermentation-produced chymosin (FPC) widely available (Kumar et al. 2010). More recently, recombinant camel chymosin, also known as fermentation-produced camel chymosin (FCC) (Kappeler et al. 2006), has also become commercially available.

The type of rennet can influence the primary proteolysis. For example, Sheehan et al. (2004) showed that reduced-fat Mozzarella cheese made with $R$. pusillus proteinase resulted in higher levels of $\mathrm{pH} 4.6$ soluble nitrogen during ripening, when compared to cheeses made with either FPC or $R$. miehei proteinase. The impact of FCC on the properties of Cheddar and Mozzarella has been reported previously (Govindasamy-Lucey et al. 2010; Bansal et al. 2009; Moynihan et al. 2014; Børsting et al. 2012). FCC has a much higher ratio of milk clotting activity/general proteolytic activity, known as a $\mathrm{C} / \mathrm{P}$ ratio, compared to bovine chymosin. FCC produces harder and chewier full-fat Cheddar cheese after 150 days of ripening, with a lower degree of primary proteolysis and less bitter and brothy flavours (Bansal et al. 2009). Low-fat Cheddar cheeses made with FCC are similarly harder, chewier and less bitter than cheeses made with FPC (Govindasamy-Lucey et al. 2010).

A previous study compared the effects of calf rennet with bovine pepsin and reported that a more compact structure was usually observed in Cheddar cheese made with the calf rennet (Stanley and Emmons 1977). No study appears, however, to have compared the microstructural changes that may occur during Cheddar cheese making when FCC or microbial rennet is used.

The rennet concentration applied may also affect the coagulation process and the quality of the final cheese. Increasing the rennet concentration increases the rate of enzymatic hydrolysis, with a resulting decrease in the time required for rennet-induced coagulation (Spangler et al. 1991). The effect of rennet concentration on the ripening of Cheddar cheese, however, has not been widely studied. Creamer and colleagues (1987) found that rennet concentration did not majorly affect Cheddar cheese making, besides producing a slightly soft gel when very low concentrations of rennet were added. There was no difference in fat losses to the whey, resulting in a similar fat in dry matter 
(FDM). It was also observed that as the ratio of rennet to casein increased, the amount of residual rennet also increased, with a resultant increase in the breakdown of $\alpha_{\mathrm{s} 1^{-}}$ casein $(\mathrm{CN})$ during ripening.

A reduction of up to $40 \%$ of rennet concentration was found to only minimally affect the composition of Mozzarella cheese, resulting in cheeses with similar protein, moisture, salt and calcium concentration and $\mathrm{pH}$, although the fat content did differ (Kindstedt et al. 1995). During ripening, the rate of increase in the concentration of $12 \%$ trichloroacetic acid soluble nitrogen was slower for the cheeses made with reduced rennet concentration. The concentration of $\alpha_{\mathrm{s}}-\mathrm{CN}$ and the hardness or springiness of the cheese, however, were not significantly affected. A study by Moynihan et al. (2014) also found that low-moisture part-skim Mozzarella cheese had similar hardness when made with different rennet concentrations. These studies are in contrast with a study on Gouda cheese made with ultrafiltered milk that observed a significantly harder and less bitter cheese with a twofold reduction in rennet concentration (Spangler et al. 1991). The results also differ from a previous study of Meshanger cheese that showed a direct relationship between the rennet concentration and the breakdown rate of $\alpha_{\mathrm{s} 1}-\mathrm{CN}$ in the cheese, and a related decrease in cheese firmness during ripening (de Jong 1977).

A study of the microstructure of the gel or cheese can provide further insight into the effect of rennet concentration or type during the processes of cheese manufacturing and cheese ripening. These effects might include changes in fat loss during cheese making or texture development during ripening. The effect of rennet concentration on the microstructure of fat-free Feta cheese has been investigated in this manner using TEM, where cheeses with a coarser protein network were observed with higher rennet concentrations (Wium et al. 2003). An earlier study also investigated the microstructure of Cheddar cheese with a reduced rennet-to-casein ratio; this was done, however, by lowering the amount of rennet whilst increasing the concentration of the milk using ultrafiltration (Green et al. 1981). There do not appear to be any studies that have observed the impact of different concentrations of rennet on the microstructure of Cheddar made with a standard concentration of milk protein, nor microstructure studies that follow such cheeses during ripening.

In this study, we investigated the impact of the concentration of the microbial rennet, Hannilase, on the composition, proteolysis and microstructure of reduced fat Cheddar cheese during production and ripening. This microbial rennet from $R$. miehei is widely used within the Australian dairy industry. We also prepared some cheeses with FCC rennet (rarely used in Australia but yet of industrial interest) as a comparison. We chose reduced-fat cheese to confirm whether microstructural changes during ripening would be different to changes previously observed with Hannilase for full-fat Cheddar (Soodam et al. 2014, 2015).

\section{Materials and methods}

\subsection{Determination of cutting time of gel during cheese making}

The storage modulus $\left(\mathrm{G}^{\prime}\right)$ of the milk was determined prior to cheese making, in order to determine the cutting time of the gel, using an Advanced Rheometric Expansion System rheometer (TA Instruments, New Castle, DE, USA), equipped with a 34-mm- 
diameter cup and a bob $33 \mathrm{~mm}$ long and $32 \mathrm{~mm}$ wide. For this experiment, milk was obtained from local suppliers, with a protein-to-fat ratio of $1.54 \pm 0.02$, a similar composition to the cheese milk used in later experiments. Starter bacteria $\left(0.05\right.$ g. $\left.\mathrm{L}^{-1}\right)$ were added to the warm $\left(33{ }^{\circ} \mathrm{C}\right)$ cheese milk. Rennet (Hannilase or Chy-Max M, Chr. Hansen) was added once the $\mathrm{pH}$ was $\sim 6.5$, and the sample $(15 \mathrm{~mL})$ was then immediately added to the cup. Hannilase rennet concentrations of 0.026 international milk clotting units (IMCU). $\mathrm{g}^{-1}$ of milk (low), 0.052 IMCU.g ${ }^{-1}$ of milk (control) and 0.150 IMCU.g $^{-1}$ of milk (high) as well as FCC rennet concentration of 0.052 IMCU.g $^{-1}$ of milk were used. The changes in the rheology of the milk during the coagulation process were then monitored using a dynamic time sweep analysis (7200 s) with an angular frequency of $0.8 \mathrm{~Hz}$ and a strain of $1 \%$. The cutting time of the gel was taken as the time taken to reach a $\mathrm{G}^{\prime}$ of $50 \mathrm{~Pa}$, based on the cutting time for the control sample.

\subsection{Cheddar cheese production}

Eight batches of cheese were made in total over the course of three trials carried out at laboratory scale using a method for manufacture described in a previous study (Ong et al. 2013). Three batches of cheese were made in duplicate with Hannilase, a microbial rennet (750 IMCU. $\mathrm{mL}^{-1}$, Chr. Hansen, Bayswater, Australia) from $R$. miehei, using concentrations of 0.026 IMCU.g $^{-1}$ of milk (low), 0.052 IMCU.g ${ }^{-1}$ of milk (control) and 0.150 IMCU.g $^{-1}$ of milk (high). Another batch of cheese was also made in duplicate with Chy-Max M (FCC, 1000 IMCU.mL ${ }^{-1}$, Chr. Hansen) using the same rennet strength (IMCU.g ${ }^{-1}$ of milk) as the control treatment with Hannilase, i.e. 0.052 IMCU.g $^{-1}$ of milk. Rennet concentrations were supplied by the manufacturer.

The cheese was made with $20 \mathrm{~kg}$ of pasteurised (at $73{ }^{\circ} \mathrm{C}$ for $15 \mathrm{~s}$ ) and standardised cheese milk, obtained from a local dairy manufacturer, with a protein-to-fat ratio of $1.54 \pm 0.02$. The cheese milk was standardised by total skimming and blending the milk with cream and ultrafiltration retentate obtained from whole milk. The cheeses were made in a randomised order. The cheese milk was warmed to $33{ }^{\circ} \mathrm{C}$ before inoculation with freeze-dried direct vat set (DVS) mesophilic/thermophilic blend lactic starter culture $\left(0.05 \mathrm{~g} . \mathrm{kg}^{-1}\right.$ of milk, Chr. Hansen), which contained strains of Streptococcus thermophilus, Lactococcus lactis subsp. cremoris and L. lactis subsp. lactis. Rennet (Hannilase or Chy-Max M) was added once the $\mathrm{pH}$ was $\sim 6.5$. The setting time was varied $(15-50 \mathrm{~min})$ to ensure similar gel strength at cutting. Once the gel coagulated, the curd was cut using a curd cutter with 1-cm-spaced wire blades and cooked. Cooking was done by gradually increasing the temperature from 33 to $38{ }^{\circ} \mathrm{C}$ in a total of $\sim 40 \mathrm{~min}$, while the stirring rate was gradually increased from 12 to $40 \mathrm{rpm}$. The curd was then cooked at $38{ }^{\circ} \mathrm{C}$ with this maximum stirring speed of $40 \mathrm{rpm}$, until the $\mathrm{pH}$ was $\sim 6.2$. The sweet whey was drained and the cheddaring step started. When the $\mathrm{pH}$ reached approximately 5.4, the curd was milled and salted with $2.5 \%(w / w)$ of salt (based on the weight of the curd) before being pressed at $\sim 440 \mathrm{kPa}$ overnight at room temperature. The cheese was then stored at $8{ }^{\circ} \mathrm{C}$ for ripening and analysed at 
weeks 1, 5, 18 and 31. The yield of cheese (Ya) was expressed as the mass of the cheese per gram of cheese milk, measured using a weighing balance. The dry matter cheese yield was calculated using the following equation:

$$
\begin{aligned}
\text { Dry matter cheese yield }(\% w / w)= & \frac{\text { mass of cheese }}{\text { mass of cheese milk }} \\
& \times \frac{100-\text { moisture content }}{100} \times 100
\end{aligned}
$$

On a separate day, gel freshly prepared at $33{ }^{\circ} \mathrm{C}$ using the same coagulation time as during the cheese making was analysed within 20 min after coagulation, using confocal laser scanning microscopy.

\subsection{Residual rennet in the fresh cheese}

An aqueous phase extract of each cheese sample was prepared (Hurley et al. 1999). The heptapeptide (30 $\left.\mu \mathrm{L}, 1 \mathrm{mg} \cdot \mathrm{mL}^{-1}\right)$ Pro-Thr-Glu-Phe- $\left[\mathrm{NO}_{2}-\mathrm{Phe}\right]-$ Arg-Leu (Bachem, Bubendorf, Switzerland) was mixed with sodium formate buffer $\left(200 \mu \mathrm{L}, 0.1\right.$ mol. $\mathrm{L}^{-1}$, pH 3.2, 0.05\% sodium azide (Chem-Supply, Gillman, Australia)) and the aqueous cheese extract $(70 \mu \mathrm{L})$. The sodium formate buffer was prepared from 0.1 M formic acid (Ajax FineChem, Seven Hills, Australia) and $0.1 \mathrm{M}$ sodium formate (Chem-Supply). The sample was then incubated at $37{ }^{\circ} \mathrm{C}$ for $5 \mathrm{~h}$, before heating for $13 \mathrm{~min}$ at $70{ }^{\circ} \mathrm{C}$ and freezing for future analysis.

The $300-\mu \mathrm{L}$ sample described above was mixed with $300 \mu \mathrm{L}$ of trifluoroacetic acid $\left(0.2 \%\right.$, Chem-Supply) and again incubated overnight at $4{ }^{\circ} \mathrm{C}$, before centrifugation for $10 \mathrm{~min}$ at $16,000 \mathrm{~g}$ using a bench top centrifuge (Eppendorf, Macquarie Park, Australia). A sample of this solution was analysed using an Agilent 1100 Series HPLC (Agilent Technologies, Santa Clara, CA, USA), equipped with an autosampler, UV detector and column oven. The column used was a $5 \mu \mathrm{m}$ Phenomenex column Jupiter 5U C18, with dimensions of $250 \times 4.6 \mathrm{~mm}$ (Phenomenex, Lane Cove West, Australia). The two solvents for the mobile phase were (A) $0.1 \%$ TFA in water and (B) $0.1 \%$ TFA in acetonitrile (Merck, Kilsyth, Australia). The flow rate was set at $1 \mathrm{~mL} \cdot \mathrm{min}^{-1}$, the wavelength was $290 \mathrm{~nm}$, and the gradient applied was as follows: $0-25 \% \mathrm{~B}, 25 \mathrm{~min} ; 25-50 \% \mathrm{~B}, 5 \mathrm{~min} ; 50 \% \mathrm{~B}$, $15 \mathrm{~min} ; 50-0 \% \mathrm{~B}, 5 \mathrm{~min}$; and $0 \% \mathrm{~B}, 10 \mathrm{~min}$.

Control samples prepared with standard rennet concentrations (0-0.004 and 0-0.01 IMCU. $\mathrm{mL}^{-1}$ for Hannilase and FCC respectively) were used to develop a calibration curve. The FCC rennet was observed to result in $3 \%$ of the amount of peptide obtained from Hannilase, under the same conditions. The results are expressed as the concentration of residual rennet in the cheese (IMCU.g ${ }^{-1}$ cheese), or as the percentage of rennet retained in the cheese, calculated as a percentage of the initial concentration of rennet added to the milk. The concentration of residual rennet in the cheese can be used to indicate the potential proteolytic activity during ripening while the percentage of rennet retained is typically used as a comparative measure for different rennet types. Analysis of residual rennet was conducted two times for each cheese. 


\subsection{Microscopy techniques - confocal laser scanning microscopy and cryo-scanning electron microscopy of gel, curd and cheese}

The gel, curd and cheese samples were analysed by confocal laser scanning microscopy (CLSM; Leica TCS SP2 or Leica SP5; Leica Microsystems, Heidelberg, Germany) and cryo-scanning electron microscopy of gel (cryo-SEM; Quanta; Fei Company, Hillsboro, OR, USA), using methods described in a previous study (Ong et al. 2011). Stock solutions of Nile Red and Fast Green FCF were prepared at a concentration of $1 \mathrm{mg} \cdot \mathrm{mL}_{-1}$ in dimethyl sulfoxide and water respectively and both stains were diluted tenfold in water prior to staining. The emission wavelengths were set at 550-600 and 668-708 nm for Nile Red and Fast Green FCF respectively. Analysis of the CLSM images was then carried out using Imaris image processing software (Bitplane, South Windsor, CT, USA), as described previously for the three-dimensional quantitative analysis of Cheddar cheese microstructure (Ong et al. 2012), using a sample volume of $\sim 55,000 \mu^{3}$ to normalise parameters such as number of vertices and number of fat globules. Parameters obtained using this method are described in a previous study (Soodam et al. 2014) and at least two replicate analyses were performed for each parameter for each cheese treatment.

\subsection{Analytical techniques}

Hannilase was characterised by reverse phase high-performance liquid chromatography and electrospray ionisation time-of-flight (ESI-TOF) mass spectrometry (MS) using an Agilent 6200 Series ESI-TOF spectrometer to determine the molecular weight, as this might be a factor in rennet retention. The charge series was deconvoluted to give a molecular weight of $41.24 \mathrm{~kg} \cdot \mathrm{mol}^{-1}$. The apparent molecular weight of FCC is available in the literature at $\sim 35.6-40 \mathrm{~kg} \cdot \mathrm{mol}^{-1}$ (Kappeler et al. 2006).

The fat and protein content of the milk used for cheese making was determined using a Milko Scan FT120 (Foss, NSW, Australia). The fat and protein content of the cheese was determined using the gravimetric method AS2300.1.3 (Australian Standard 2008) and the Kjeldahl method AS2300.1.2.1 (Australian Standard 1991) respectively. The salt content of the cheeses was determined using the Volhard method AS2300.6.5 (Australian Standard 1990). The moisture content of the cheeses was obtained by placing samples of known mass $(m 1)$ in pre-weighed crucibles $(m 2)$ and then drying the samples at $100 \pm 3{ }^{\circ} \mathrm{C}$ in an oven (S.E.M. Pty. Ltd., Magill, Australia) for at least $18 \mathrm{~h}$. The weight of the samples was recorded once stable $(m 3)$. The moisture content was then determined from the weight loss from the original sample of cheese, as described in the following equation:

$$
\text { Moisture content }(\% w / w)=\frac{m 1-(m 3-m 2)}{m 1} \times 100 \text {. }
$$

The fat content of the sweet whey, collected during draining and cheddaring, and the salty whey, collected during pressing, was determined using a modified version of the method described by Atwood and Hartmann (1992). A ferric chloride-trichloroacetic acid solution was obtained by mixing $10 \mathrm{~mL}$ of a solution containing $0.37 \mathrm{M} \mathrm{FeCl}_{3}$ (Ajax Finechem) and 0.1 M hydrochloric acid ( $\mathrm{HCl}$, Univar, Ajax Finechem, Australia), with $7.5 \mathrm{~g}$ trichloroacetic acid (TCA, Chem-Supply).

The whey samples were warmed to $37^{\circ} \mathrm{C}$ and diluted twofold. The diluted sample $(50 \mu \mathrm{L})$ was then mixed with ethanol $(600 \mu \mathrm{L}$, Merck), hydroxylamine hydrochloride 
(100 $\mu \mathrm{L}$ of $2 \mathrm{M}$, Ajax Finechem) and sodium hydroxide (NaOH, $100 \mu \mathrm{L}$ of $3.5 \mathrm{M}$, Chem-Supply). The resultant mixture was incubated for $30 \mathrm{~min}$ at room temperature, after which $\mathrm{HCl}(120 \mu \mathrm{L}$ of $3.4 \mathrm{M} \mathrm{HCl})$ was added to the mixture. Ferric chloridetrichloroacetic acid solution $(100 \mu \mathrm{L})$, prepared as described previously, was then mixed into the acidified solution. The mixture was then centrifuged at $1500 \mathrm{~g}$ for $5 \mathrm{~min}$, and the supernatant was dispensed into a 96-well microplate (BD Falcon, North Ryde, Australia). The absorbance of the solution was measured at $540 \mathrm{~nm}$ using a microplate reader (Fluostar Optima, BMG Labtech, Ortenberg, Germany). The fat concentration of the samples was determined by reference to standard triolein solutions (Sigma-Aldrich, Castle Hill, Australia). Two replicate analyses were performed for each cheese treatment.

A modified version of a method previously described (Pesce and Strande 1973) was used to determine the protein content of the whey. TCA-Ponceau S working reagent was prepared from TCA (Chem-Supply) and Ponceau S dye (Merck) as described by Pesce and Strande (1973). The whey sample was diluted 20 -fold and $100 \mu \mathrm{L}$ of the diluted sample was then mixed with $1 \mathrm{~mL}$ of the TCA-Ponceau $\mathrm{S}$ normal working reagent. The resulting mixture was then centrifuged at $15,000 \mathrm{~g}$ for $5 \mathrm{~min}$. The resulting precipitate was then dissolved in sodium hydroxide $\left(\mathrm{NaOH}, 0.2 \mathrm{~mol} . \mathrm{L}^{-1}, 700 \mu \mathrm{L}\right)$. The solution was dispensed into a 96-well microplate (BD Falcon), and the absorbance was measured at $560 \mathrm{~nm}$ using a microplate reader (Fluostar Optima, BMG Labtech). The protein concentration of the samples was determined by reference to standard bovine serum albumin solutions (Thermo Scientific, Rockford, IL, USA). Two replicate analyses were performed for each cheese treatment.

The $\mathrm{pH}$ of the cheese was obtained by homogenising $10 \mathrm{~g}$ of grated cheese with $10 \mathrm{~mL}$ of water. The $\mathrm{pH}$ of the slurry was then determined using an electrode $\mathrm{pH}$ meter (Orion 720A, Orion Pacific, Frankston, Australia).

The $\mathrm{pH} 4.6$ soluble extract was prepared based on the method of Sousa and McSweeney (2001). Grated cheese (10 g) was homogenised with water (20 mL) and the slurry adjusted to $\mathrm{pH} 4.6$ using hydrochloric acid $(\mathrm{HCl}, 1.0 \mathrm{M})$. The sample was then incubated at room temperature for half an hour, and the $\mathrm{pH}$ was readjusted to a value of 4.6. The mixture was then incubated in a water bath at $40{ }^{\circ} \mathrm{C}$ for $60 \mathrm{~min}$ before centrifugation at $3000 \mathrm{~g}\left(4^{\circ} \mathrm{C}, 30 \mathrm{~min}\right.$; Eppendorf). The soluble fraction found in between the upper fat layer and lower casein precipitate was filtered through Whatman No. 54 filter paper (GE Healthcare Life Sciences, Parramatta, Australia) to yield the $\mathrm{pH}$ 4.6 soluble extract. The nitrogen content of this extract was then determined using the Kjeldahl method AS 2300.1.2.1 (Australian Standard 1991). The samples were analysed once per cheese treatment.

The proteolytic pattern of the cheese during ripening was determined using sodium dodecyl sulfate polyacrylamide gel electrophoresis (SDS-PAGE). The cheese stock solution was prepared using the method of Ong et al. (2006), except that $25 \mathrm{mg}$ cheese samples were used. The stock solutions produced were then diluted approximately fourfold with Tris $\left(10\right.$ mmol.L $\left.{ }^{-1}\right)$-EDTA $\left(1\right.$ mmol.L $\left.{ }^{-1}\right)$ pH 8.0 buffer. Standards of $\alpha-C N, \beta-C N$ and $\kappa-$

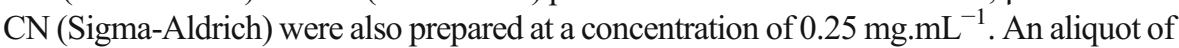
$6.5 \mu \mathrm{L}$ was mixed with $2.5 \mu \mathrm{L}$ of Bolt LDS Sample Buffer $(4 \times)$ and $1 \mu \mathrm{L}$ Bolt Reducing Agent (10×; Invitrogen, Mt Waverley, Australia). The solution was then heated at $70{ }^{\circ} \mathrm{C}$ for $10 \mathrm{~min}$ and the resulting solution loaded into a $12 \%$ acrylamide Bis-Tris Plus gel (Invitrogen). A molecular standard, SeeBlue Plus2 pre-stained (Invitrogen), was also 
loaded in each gel. Bolt 2-( $N$-morpholino)ethanesulphonic acid SDS Running Buffer (1×; Invitrogen) was used as buffer, and the system was run for $1 \mathrm{~h}$ and $15 \mathrm{~min}$ at $125 \mathrm{~V}$. The protein bands were then stained and then destained as described by Ong et al. (2006) except that $7.5 \% v / v$ acetic acid was used and the de-staining solution did not contain methanol. The gel was then scanned using a Fujifilm Intelligent Dark Box II with LAS3000 Lite V2.2 software and LAS-3000 Image Multi Gauge (Fujifilm, Brookvale, Australia) to quantify the intensity of $\alpha$ - and $\beta-\mathrm{CN}$ bands during ripening. The data presented are representative of two gels.

The hardness of cheese samples was determined using a two-bite compression test on a TA-XT Plus texture analyser (Stable Micro Systems, Surrey, UK) as the force required to compress the cheese to $50 \%$ original height at $2 \mathrm{~mm} . \mathrm{s}^{-1}$. A modification of the method of Ong et al. (2012) was used with cylindrical samples of $2.0 \mathrm{~cm}$ in diameter and $2.0 \mathrm{~cm}$ in height. Texture analysis was performed at least three times for each cheese treatment.

\subsection{Statistical analysis}

All cheese treatments were performed in duplicate, and the results presented are the mean of the two data points $(n=2)$, where all replicate analyses were averaged for each cheese. The cheese composition and processing time, the whey composition, the yield, the residual rennet analysis, the $\mathrm{pH} 4.6$ soluble nitrogen and the image analysis of the gel and curd were analysed using one-way analysis of variance and Tukey's paired comparison, with a significance level of $\alpha=0.05$. For all other analyses, a parameter ID $(\mathrm{ID}=1,2,3,45,6,7,8)$ was assigned to each of the eight batches of cheese. This parameter helped to link the original cheeses to the cheeses during ripening. The experimental results were then analysed using "General Analysis of Variance" in GenStat (VSN International, Hemel Hempstead, UK). If changes due to time or rennet were significant, the data were further analysed using Tukey's paired comparison, with a significance level of $\alpha=0.05$. A Tukey's paired comparison, with a significance level of $\alpha=0.05$, was used to analyse the residual rennet treatment (low, high Hannilase rennet concentration, FCC rennet) with respect to the control. Multiple linear regression (Microsoft Excel) was also used to analyse the texture during ripening.

\section{Results and discussion}

\subsection{The effect of rennet on the storage modulus ( $\left.G^{\prime}\right)$, cutting time of the gel and processing time of cheese making}

A rheological experiment was carried out prior to the cheese making to determine the required cutting time for the gel. The effect of rennet concentration and type on the gel strength is shown in Fig. 1. As the Hannilase rennet concentration increased from control to high (from 70 to $200 \mu \mathrm{L} . \mathrm{kg}^{-1}$ of milk), the gel strength and rate of gel strength development increased due to increased enzymatic hydrolysis. FCC also induced a faster change in gel strength when compared to Hannilase (control), despite the similar rennet strength used, resulting in a decrease in cutting time with this enzyme. This may be due to the higher milk clotting activity of FCC with respect to the proteinase from $R$. miehei (Kappeler et al. 2006). 


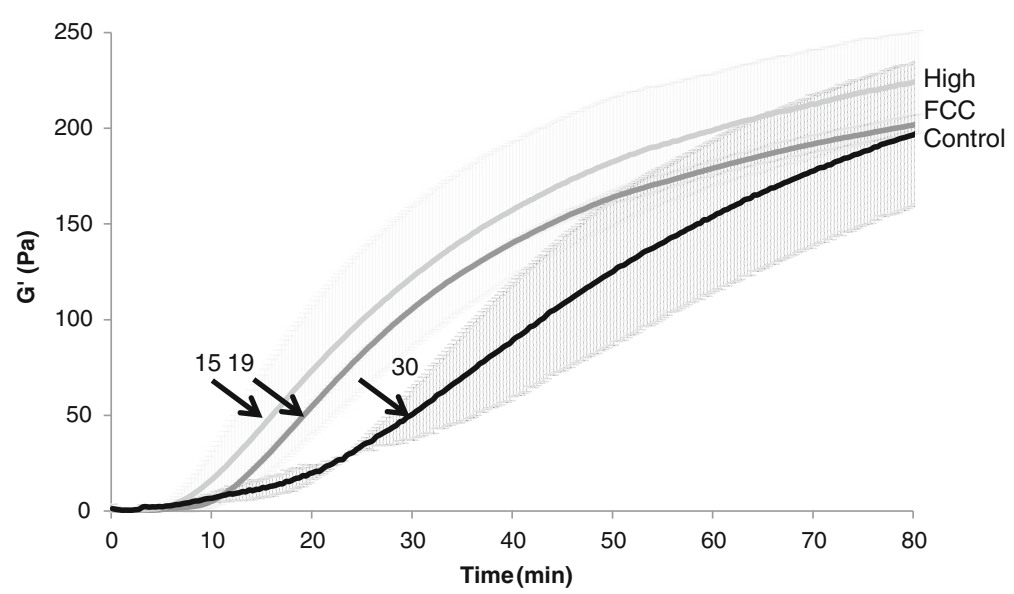

Fig. 1 The storage modulus $\left(\mathrm{G}^{\prime}\right)$ measured from the time of rennet addition for milk with control (black solid line) or high (light grey solid line) Hannilase rennet concentration or fermentation-produced camel chymosin (dark grey solid line). Arrows indicate the time when the $\mathrm{G}^{\prime}$ measured reached $50 \mathrm{~Pa}$ (defined as the cutting time) and the shaded region indicates the error bars. The results are expressed as the mean \pm the standard deviation of the mean $(n=2)$

The cutting time was defined here as the time required to reach $\mathrm{G}^{\prime}$ of $50 \mathrm{~Pa}$ (Fig. 1). The control, high and FCC samples were cut at 30,15 and 19 min during the cheese making. The gel made from low rennet treatment was too soft to be measured using the rheological test and was instead determined during the actual cheese making. The time required for the gel with low rennet concentration to reach a medium firmness, as determined by an experienced cheese maker, was found to be $50 \mathrm{~min}$.

Increasing the rennet concentration or using FCC resulted in a decrease in coagulation time, as discussed above. All four treatments, however, had a statistically similar $(P>0.05)$ total processing time (from starter addition to milling; Table 1), showing that a change in rennet concentration or rennet type will not affect plant productivity.

\subsection{Fat and protein loss, yield and composition of the cheeses}

The protein and fat lost to the sweet and salty whey were not significantly different between treatments, (Table 2). It should be noted that while the fat and protein loss to the sweet whey of the low rennet treatment appears lower than the other three treatments, the results are not significant due to large standard deviations. The composition of the cheese (fat, protein, moisture, salt, FDM, salt in moisture (S/M), moisture in fat-free substance (MFFS)), shown in Table 1, were all statistically similar $(P>0.05)$ between treatments. Similar observations were made in previous studies; S/M, MFFS (Creamer et al. 1987), protein, moisture and salt (Kindstedt et al. 1995) were similar for cheeses made with different rennet concentrations. The results are also consistent with previous studies where a similar composition was reported for full-fat or low-fat Cheddar cheese made with FCC and FPC (Bansal et al. 2009; Govindasamy-Lucey et al. 2010). The fat content was observed, however, to be significantly affected by coagulant concentration in Mozzarella cheese (Kindstedt et al. 1995), in contrast to this study, although the cause of this difference is not known. 


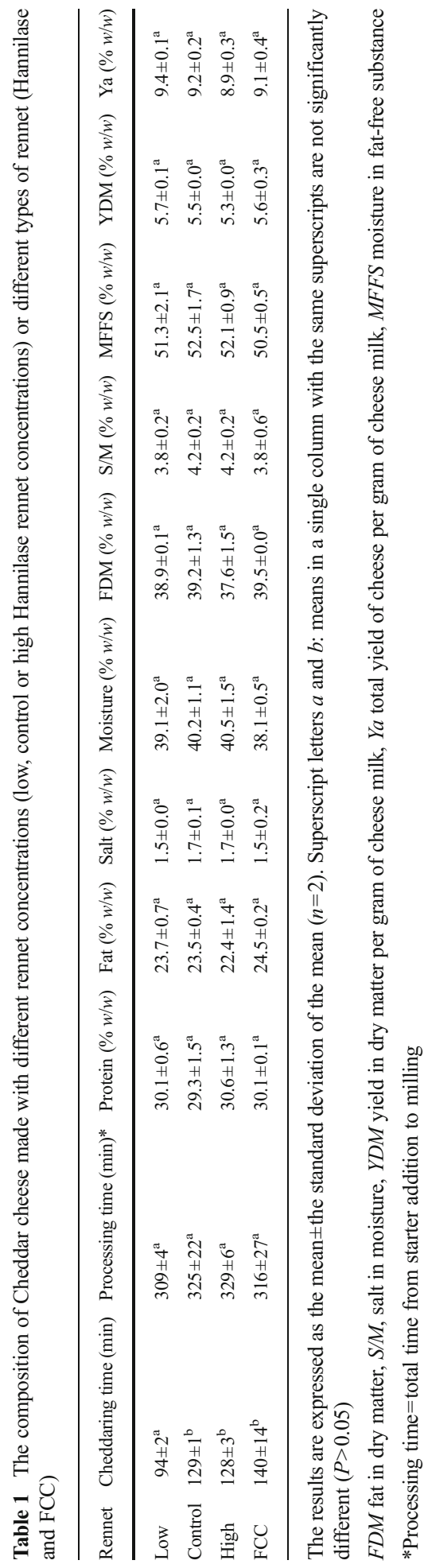


Table 2 The fat and protein composition of whey made with different rennet concentrations (low, control or high Hannilase rennet concentrations) or different types of rennet (Hannilase and fermentation-produced camel chymosin, FCC)

\begin{tabular}{|c|c|c|c|c|c|c|c|c|c|c|}
\hline \multirow[t]{2}{*}{ Rennet } & \multicolumn{5}{|l|}{ Sweet whey } & \multicolumn{5}{|l|}{ Salty whey } \\
\hline & $\begin{array}{l}\text { Weight of } \\
\text { whey }(\mathrm{kg})\end{array}$ & $\begin{array}{l}\text { Fat } \\
(\% w / w)\end{array}$ & $\begin{array}{l}\text { Protein } \\
(\% w / w)\end{array}$ & $\begin{array}{l}\mathrm{FL} \\
(\% w / w)\end{array}$ & $\begin{array}{l}\mathrm{PL} \\
(\% w / w)\end{array}$ & $\begin{array}{l}\text { Weight of } \\
\text { whey }(\mathrm{kg})\end{array}$ & $\begin{array}{l}\text { Fat } \\
(\% w / w)\end{array}$ & $\begin{array}{l}\text { Protein } \\
(\% w / w)\end{array}$ & $\begin{array}{l}\mathrm{FL} \\
(\% w / w)\end{array}$ & $\begin{array}{l}\mathrm{PL} \\
(\% w / w)\end{array}$ \\
\hline Low & $\begin{array}{r}17.33 \pm \\
0.05^{\mathrm{a}}\end{array}$ & $\begin{array}{l}0.16 \pm \\
0.07^{\mathrm{a}}\end{array}$ & $\begin{array}{l}0.86 \pm \\
0.25^{\mathrm{a}}\end{array}$ & $\begin{array}{l}5.13 \pm \\
2.17^{\mathrm{a}}\end{array}$ & $\begin{array}{r}17.67 \pm \\
4.97^{\mathrm{a}}\end{array}$ & $\begin{array}{l}0.19 \pm \\
0.02^{\mathrm{a}}\end{array}$ & $\begin{array}{l}0.16 \pm \\
0.05^{\mathrm{a}}\end{array}$ & $\begin{array}{l}0.86 \pm \\
0.00^{\mathrm{a}}\end{array}$ & $\begin{array}{l}0.06 \pm \\
0.02^{\mathrm{a}}\end{array}$ & $\begin{array}{l}0.20 \pm \\
0.02^{\mathrm{a}}\end{array}$ \\
\hline Control & $\begin{array}{r}17.28 \pm \\
0.10^{\mathrm{a}}\end{array}$ & $\begin{array}{l}0.23 \pm \\
0.07^{\mathrm{a}}\end{array}$ & $\begin{array}{l}1.23 \pm \\
0.23^{\mathrm{a}}\end{array}$ & $\begin{array}{l}7.40 \pm \\
2.23^{\mathrm{a}}\end{array}$ & $\begin{array}{r}25.25 \pm \\
4.69^{\mathrm{a}}\end{array}$ & $\begin{array}{l}0.15 \pm \\
0.03^{\mathrm{a}}\end{array}$ & $\begin{array}{l}0.19 \pm \\
0.01^{\mathrm{a}}\end{array}$ & $\begin{array}{l}0.69 \pm \\
0.15^{\mathrm{a}}\end{array}$ & $\begin{array}{l}0.05 \pm \\
0.01^{\mathrm{a}}\end{array}$ & $\begin{array}{r}0.13 \pm \\
0.05^{\mathrm{a}}\end{array}$ \\
\hline High & $\begin{array}{r}17.37 \pm \\
0.00^{\mathrm{a}}\end{array}$ & $\begin{array}{l}0.22 \pm \\
0.01^{\mathrm{a}}\end{array}$ & $\begin{array}{l}1.19 \pm \\
0.16^{\mathrm{a}}\end{array}$ & $\begin{array}{l}6.86 \pm \\
0.51^{\mathrm{a}}\end{array}$ & $\begin{array}{r}24.51 \pm \\
3.40^{\mathrm{a}}\end{array}$ & $\begin{array}{l}0.16 \pm \\
0.03^{\mathrm{a}}\end{array}$ & $\begin{array}{l}0.12 \pm \\
0.04^{\mathrm{a}}\end{array}$ & $\begin{array}{l}0.64 \pm \\
0.08^{\mathrm{a}}\end{array}$ & $\begin{array}{l}0.03 \pm \\
0.02^{\mathrm{a}}\end{array}$ & $\begin{array}{l}0.12 \pm \\
0.01^{\mathrm{a}}\end{array}$ \\
\hline FCC & $\begin{array}{r}17.36 \pm \\
0.00^{\mathrm{a}}\end{array}$ & $\begin{array}{r}0.25 \pm \\
0.00^{\mathrm{a}}\end{array}$ & $\begin{array}{c}1.21 \pm \\
0.02^{\mathrm{a}}\end{array}$ & $\begin{array}{l}8.06 \pm \\
0.16^{\mathrm{a}}\end{array}$ & $\begin{array}{r}25.11 \pm \\
0.84^{\mathrm{a}}\end{array}$ & $\begin{array}{r}0.14 \pm \\
0.03^{\mathrm{a}}\end{array}$ & $\begin{array}{l}0.22 \pm \\
0.06^{\mathrm{a}}\end{array}$ & $\begin{array}{r}0.70 \pm \\
0.05^{\mathrm{a}}\end{array}$ & $\begin{array}{r}0.06 \pm \\
0.03^{\mathrm{a}}\end{array}$ & $\begin{array}{r}0.12 \pm \\
0.04^{\mathrm{a}}\end{array}$ \\
\hline
\end{tabular}

Results are expressed as mean \pm standard deviation of mean $(n=2)$. Superscript letter $a$ : means in a single column with the same superscripts are not significantly different $(P>0.05)$

$F L$ fat lost per kilogram of fat in the cheese milk, $P L$ protein lost per kilogram of protein in the cheese milk

The yield (Ya) and yield in dry matter (YDM) were also not significantly different between cheese treatments here $(P>0.05)$ when all four treatments were analysed together. Statistical analysis of only the cheeses made with Hannilase, however, showed a decreasing trend in the YDM as rennet concentration increased $(P<0.05)$. It is not known why increasing Hannilase concentration should result in a decrease in the YDM, and further work is needed to elucidate this mechanism. The yield value of 8.9-9.4\% $\mathrm{w} /$ $w$ was slightly higher than that observed in a previous study investigating reduced-fat Cheddar cheese $(8.09 \%$ w/w) (Fenelon and Guinee 1999). However, the cheese milk used in our study was standardised using ultrafiltration and also adjusted to a lower protein-to-fat ratio, meaning that simple yields (calculated as mass yield per volume of milk) are not directly comparable.

Generally, cheese made with rennet with a more specific enzyme activity (high $\mathrm{C} / \mathrm{P}$ ratio) should result in higher cheese yields due to less loss of protein to the whey, an observation made in studies of $R$. miehei coagulants and bovine chymosin (Ustunol and Hicks 1990). It is unknown why similar yields were obtained in this study. It is possible that the different variants of the $R$. miehei microbial rennet used in the different studies might account for the results obtained. Alternatively, differences in yields are usually less than $1 \%$, and it is possible that the scale of the experiment is too small for these differences to be observed. Furthermore, statistically similar cheese yields were also obtained when FCC and FPC were compared (Bansal et al. 2009), even though FCC has higher selectivity $(\mathrm{C} / \mathrm{P})$ than FPC. The current study provides further evidence that Hannilase and FCC can be used interchangeably without large changes in cheese composition.

\subsection{Residual rennet in cheese}

The concentration of residual rennet activity in the cheeses made with a low Hannilase rennet concentration was significantly lower than in the control cheese (Table 3), as 
Table 3 Residual rennet and rennet retention in Cheddar cheese made with different rennet concentrations (low, control or high Hannilase rennet concentrations) or different types of rennet (Hannilase and fermentation-produced camel chymosin, FCC)

\begin{tabular}{lllc}
\hline Rennet & Rennet added to milk (IMCU.g ${ }^{-1}$ of milk) & Residual rennet (IMCU.g ${ }^{-1}$ of cheese) & Rennet retention (\%) \\
\hline Low & 0.026 & $0.0044 \pm 0.0005 *$ & $1.59 \pm 0.16$ \\
Control & 0.052 & $0.0066 \pm 0.0001$ & $1.16 \pm 0.04$ \\
High & 0.150 & $0.0063 \pm 0.0001$ & $0.38 \pm 0.02 *$ \\
FCC & 0.052 & $0.1891 \pm 0.0053 *$ & $32.60 \pm 0.66 *$ \\
\hline
\end{tabular}

The results are expressed as the mean \pm the standard deviation of the mean $(n=2)$

* Results are statistically different based on pairwise comparison with respect to the control cheese $(P<0.05)$

${ }^{a}$ Results for rennet retention are expressed as the percentage of rennet present in the total amount of cheese produced over the total amount of enzyme added to the milk

might be expected. The percentage of the rennet activity retained, however, was similar. Past studies have all shown that increasing the calf rennet concentration will increase the residual rennet concentration in the cheese (Dulley 1974; Creamer et al. 1987), in agreement with these results. When the Hannilase concentration was increased beyond the control value $\left(>0.052\right.$ IMCU.g $^{-1}$ milk), however, the residual rennet concentration did not increase further (Table 3). As a result, the percentage retention of rennet was lower $(P<0.05)$. These results suggest that there is a critical Hannilase concentration above which further retention of rennet activity in the curd does not occur, with a subsequent decrease in the percentage of residual rennet activity in the cheese.

The FCC rennet clotting activity when added to the milk was the same as that used for the control cheese made with Hannilase rennet (Table 3), yet the residual rennet activity in the FCC cheese was significantly higher, with a difference of $~ 29$-fold. It should be noted, however, that the sensitivity of the two assays differed for the two enzymes. Previous studies have found the retention of microbial rennet to be typically low, at $\sim 2-3 \%$ (Holmes et al. 1977), broadly consistent with the fraction of the milk aqueous phase entrapped in the curd. On the other hand, retention of FCC activity was found to be $\sim 20 \%$ within the $\mathrm{pH}$ range of 6.65-6.00 (Børsting et al. 2014), consistent with the retentions found in this study.

The residual rennet activity is a function of both the physical retention of rennet in the curd and the loss of rennet activity due to denaturation, proteolysis or other damage to the enzyme during cheese manufacture. The apparent molecular weight of FCC is 35.6-40 kg.mol ${ }^{-1}$ (Kappeler et al. 2006), and the molecular weight of the proteinase from $R$. miehei was found here to be $\sim 41.24 \mathrm{~kg} \cdot \mathrm{mol}^{-1}$ by ESI-TOF mass spectrometry. It is therefore unlikely that the retention was influenced by the size of the rennet enzyme but other possible factors may be responsible, such as electrostatic interactions with caseins or the enzyme surface hydrophobicity. For the $\mathrm{pH}$ of 6.2 for whey draining used here, the net charge, calculated based on known $\mathrm{p} K_{\mathrm{a}}$ values and the HendersonHasselbalch equation (Moore 1985; Berg et al. 2007) for the FCC and R. miehei, would be approximately -8 and -19 . This may contribute to the difference in retention observed due to different interactions with the negatively charged caseins and at higher concentrations of Hannilase rennet this may also potentially result in more expulsion into the whey due to these repulsive forces. 
In the study by Holmes et al. (1977), it was shown that the activity of calf rennet decreased during cheese making but that the activity of the Mucor miehei rennet was not affected at the point of whey removal. The strain of enzyme used in this prior study, however, is different to the enzymes typically used commercially, which are often chemically modified to reduce their heat stability. We have no data on the relative stability of the commercial Hannilase enzyme free in solution versus the enzyme when associated with caseins or other curd components but our results lead us to hypothesise that there may be a stable enzyme fraction (stabilised by specific binding to caseins) and that the upper boundary for that fraction is determined by the number of available binding sites. If so, any free enzyme may be more readily heat-inactivated during cheese making and this effect will be more pronounced for the samples with higher concentrations of Hannilase.

\subsection{Effect of rennet concentration and type on the microstructure of the gel}

The CLSM and cryo-SEM images of the freshly formed gels are shown in Fig. 2. From the images, the gel structure appears as a porous protein network, with spherical fat globules dispersed throughout. Qualitatively, increasing the concentration of rennet per mass of protein from low to high (Fig. $2 \mathrm{a}-\mathrm{c}, \mathrm{e}-\mathrm{g}$ ), appears to increase the porosity of the gel. This was not observed in the quantitative data from image analysis due to high variability in the data $(P>0.05$, Table 4$)$. A more porous gel made with a higher concentration of rennet could contribute to a higher loss of rennet from this gel, resulting in the lower rennet retention for these samples (Table 3). Any difference in gel structure porosity also has the potential to affect fat loss to the whey (Ong et al. 2015), as well as the texture of the resultant cheese; a denser network may then result in

Low
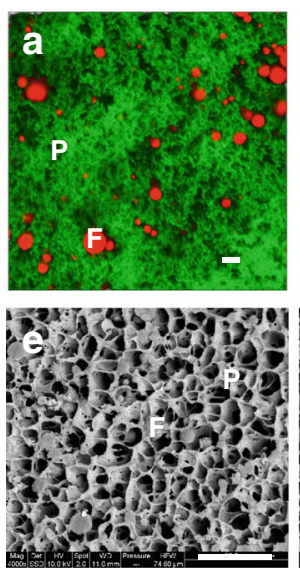

Control
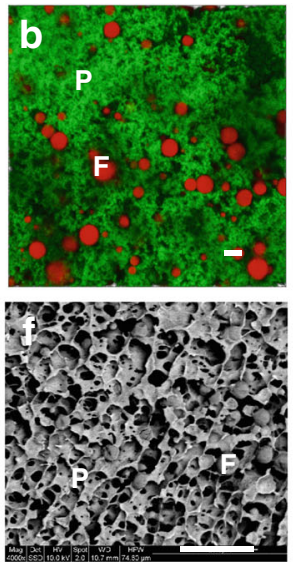

High
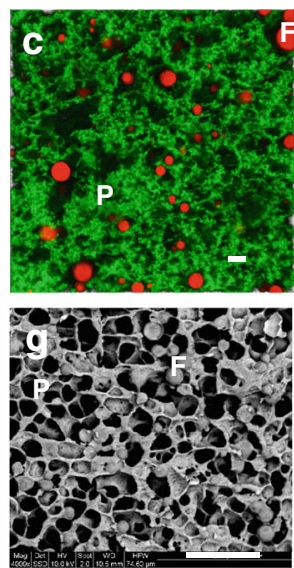

FCC
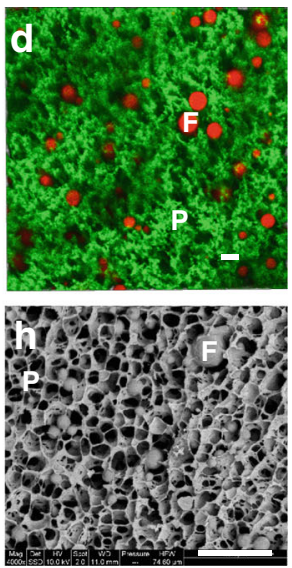

Fig. 2 Three-dimensional (3D) confocal microscopy images (a-d) and cryo-scanning electron microscopy images $(\mathbf{e}-\mathbf{h})$ of the microstructure of gels made using low $(\mathbf{a}, \mathbf{e})$, control $(\mathbf{b}, \mathbf{f})$ or high $(\mathbf{c}, \mathbf{g})$ Hannilase rennet concentration or fermentation-produced camel chymosin (d, h). Protein is stained green (FCF) and fat is stained red (Nile Red). The confocal images are 3D reconstructions built from 40 layers, adding up to a total depth of $10 \mu \mathrm{m}$. Cryo-scanning electron microscopy images were captured using a solid state detector at a magnification of $\times 4000$. The scale bars are $10 \mu \mathrm{m}(\mathbf{a}-\mathbf{d})$ or $20 \mu \mathrm{m}(\mathbf{e}-\mathbf{h})$ in length. Images can be viewed in colour in the electronic version of this manuscript. $F$ indicates fat globules and $P$ indicates protein 
Table 4 Porosity determined from 3D confocal microscopy images of the gel made with low, control or high concentrations of Hannilase rennet concentration or fermentation-produced camel chymosin, FCC

\begin{tabular}{lr}
\hline Rennet & Porosity \\
\hline Low & $0.41 \pm 0.05^{\mathrm{a}}$ \\
Control & $0.48 \pm 0.03^{\mathrm{a}}$ \\
High & $0.52 \pm 0.07^{\mathrm{a}}$ \\
FCC & $0.52 \pm 0.04^{\mathrm{a}}$ \\
\hline
\end{tabular}

The results are expressed as the mean \pm the standard deviation of the mean $(n=2)$. Superscript letter $a$ : means in a single column with similar superscripts are not significantly different $(P>0.05)$

a harder cheese (Ong et al. 2013). Similar fat and protein losses in the whey were observed in this study $(P>0.05$, Table 2$)$, however, suggesting that the enzymes can be interchanged without undesirable changes in cheese properties.

The microstructure of the control gel (Fig. 2b, f) and the gel made with FCC treatment (Fig. 2d, h) did not differ significantly. The porosity obtained was similar (Table 4), despite the difference in gelation obtained for these two treatments (Fig. 1). The similar porosity of the control and FCC treatment but higher retention of rennet observed in FCC cheese suggests, however, that factors other than porosity also influence the retention of rennet in cheese, as discussed in the previous section (Sect. 3.3).

\subsection{The effect of rennet concentration and type on the microstructure of cooked curd, milled curd, fresh cheese and cheese during ripening}

The structural differences visible in the gel due to the different rennet treatments are less obvious in the cooked and milled curd. No significant differences in porosity were found by qualitative observation (Fig. 3) or quantitative analysis of images $(P>0.05$; data not shown). It is possible that the difference
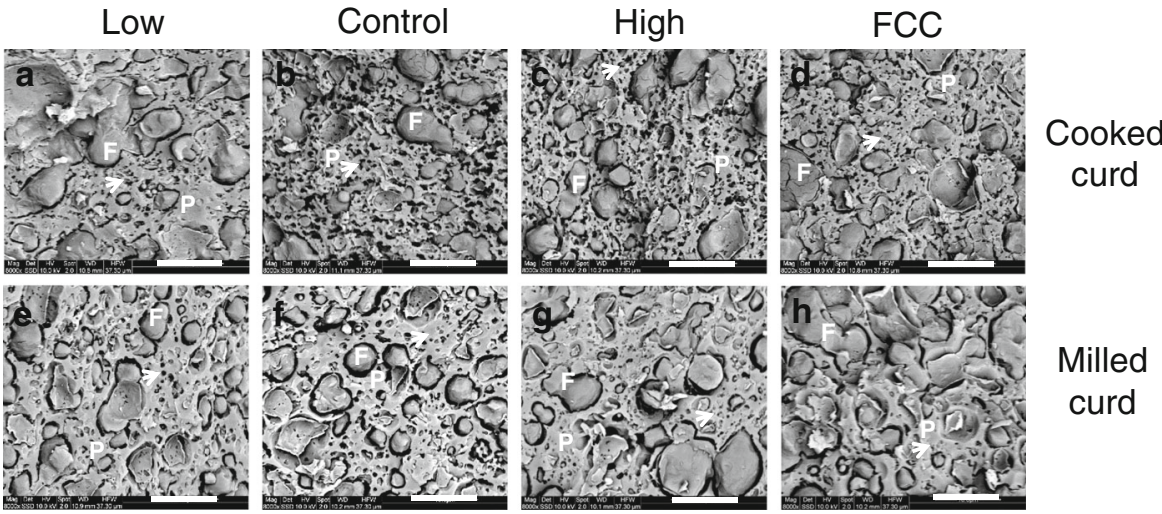

curd

Fig. 3 Cryo-scanning electron microscopy images of cooked $(\mathbf{a}-\mathbf{d})$ and milled curd (e-h) made using low (a, e), control $(\mathbf{b}, \mathbf{f})$ or high $(\mathbf{c}, \mathbf{g})$ Hannilase rennet concentration or fermentation-produced camel chymosin rennet $(\mathbf{d}, \mathbf{h})$. Cryo-SEM images were captured using a solid state detector at a magnification of $\times 8000$. The scale bars are $10 \mu \mathrm{m}$ in length, $F$ indicates fat globules, $P$ indicates protein, and the arrows indicate micropores 
in cheddaring time for the different treatments may have played a role in these results (Table 1). Micropores are visible in the cryo-SEM images of the cooked and milled curd across the treatments (Fig. 3). Generally, the rennet concentration used did not significantly affect the number and diameter of fat globules in the cooked curd or milled curd $(P>0.05)$.

The microstructure of the fresh cheese observed by cryo-SEM is shown in Fig. $4 \mathrm{a}-\mathrm{d}$. The micropores that were previously visible in the cooked and milled curd (Fig. 3) are now all pressed closed. Qualitatively, the microstructure of the four different types of fresh cheeses was similar, irrespective of the treatment used. After ripening for 31 weeks, however, the microstructure of the cheeses as observed using cryo-SEM appeared visually different (Fig. 4e-h), with a thicker protein network in the FCC cheese compared to the cheeses made using Hannilase. This difference may arise as a result of the lower general proteolytic activity of FCC compared to Hannilase (Kappeler et al. 2006; Martin et al. 1980). Although determined under different experimental conditions, Kappeler et al. (2006) indicated that the $R$. miehei proteinase is approximately six times more proteolytic than FCC, based on the nonspecific hydrolysis of casein.

The number of fat globules as well as number of vertices, a measure which may indicate the branching of the rendered protein surface (Soodam et al. 2014), determined by quantitative CLSM image analysis, was not significantly affected by rennet or ripening time (data not shown). In a previous study, a significant decrease in the number of vertices was observed with ripening (Soodam et al. 2014). The trend observed in this study may be due to either the shorter ripening period, the use of reduced fat cheeses instead of full fat cheeses, or the different magnifications used in capturing the CLSM images, as images were captured at $\times 100$ instead of $\times 63$ as was previously used, to allow a better resolution of the structure.
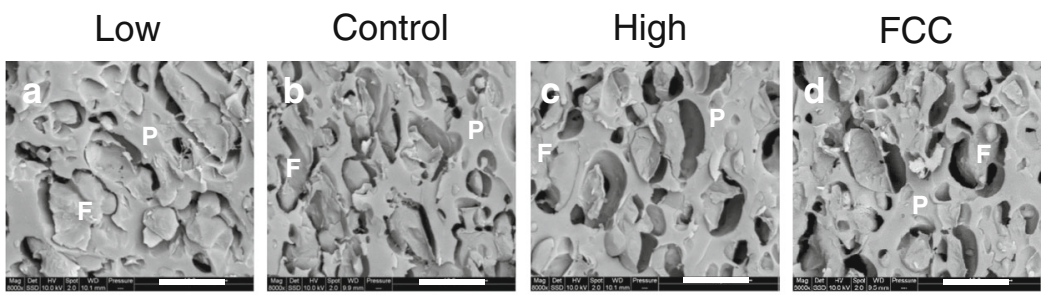

Week
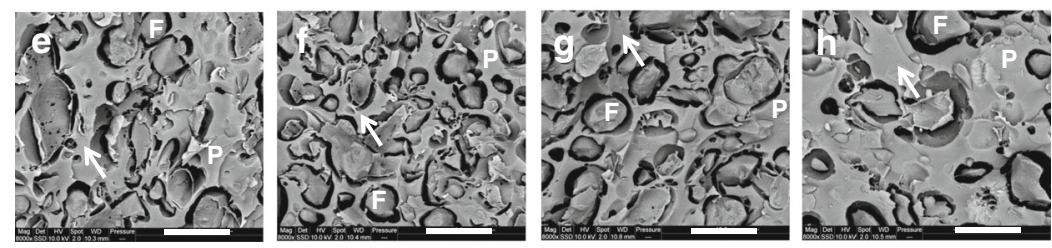

Week

Fig. 4 Cryo- scanning electron microscopy images of the microstructure of freshly pressed (a-d) and mature cheeses $(\mathbf{e}-\mathbf{h})$ made using low $(\mathbf{a}, \mathbf{e})$, control $(\mathbf{b}, \mathbf{f})$ or high $(\mathbf{c}, \mathbf{g})$ rennet concentration or fermentation-produced camel chymosin $(\mathbf{d}, \mathbf{h})$. Cryo-scanning electron microscopy images were captured using a solid state detector at a magnification of $\times 8000$. The scale bars are $10 \mu \mathrm{m}$ in length. $F$ indicates fat globules, $P$ indicates protein, and the arrows indicate the protein network 


\subsection{Proteolysis during ripening}

The level of proteolysis in the cheese was assessed by comparing the ratio of $\mathrm{pH} 4.6$ soluble nitrogen/total nitrogen $(\mathrm{pH} 4.6-\mathrm{SN} / \mathrm{TN})$ at the end of the ripening period (Fig. 5a). This ratio quantifies primarily the peptides released due to the action of rennet (O'Keeffe et al. 1978), although whey proteins and proteins from plasmin activity such as proteose peptones may also contribute to the $\mathrm{pH} 4.6-\mathrm{SN} / \mathrm{TN}$ to a small extent (O'Keeffe et al. 1978).

This ratio of $\mathrm{pH}$ 4.6-SN/TN increased significantly with increasing Hannilase rennet concentration $(P<0.05)$. Given the estimated amount of residual rennet in the cheeses (Table 3), it would be expected that the $\mathrm{pH} 4.6-\mathrm{SN} / \mathrm{TN}$ ratio for the control and high rennet concentration cheeses would be similar. The S/M and MFFS of the cheeses were similar, suggesting that factors other than composition may be affecting proteolysis. On the other hand, unknown factors might be affecting the estimation of residual rennet in the different cheeses. Higher proteolysis may be obtained over time (31 weeks) when more rennet is added, as observed for the high rennet treatment compared to the control rennet treatment, due to the presence of more proteinases in the cheese. This difference in rennet concentration may, however, not be significant enough to be observed in the enzyme assay described in Sect. 3.3 above.

During ripening, the $\mathrm{pH}$ increased significantly $(P<0.05$, Fig. $5 \mathrm{~b})$; the $\mathrm{pH}$ during ripening is usually affected by the formation of organic acids such as lactic acid and the buffering capacity of the cheese. A similar rise in $\mathrm{pH}$ has been observed before for reduced fat Cheddar cheese (Fenelon and Guinee 2000). In Fig. 5b, the control cheese appears to have a slower rate of $\mathrm{pH}$ increase with time, compared to the other cheeses; the cause of this difference is not currently known. The $\mathrm{S} / \mathrm{M}$ ratios for the cheeses were similar, as was the $\mathrm{pH}$ at draining. A difference in residual lactose may influence the changes in $\mathrm{pH}$ but similar milk was used for all cheeses. Similarly, the calcium and phosphorus content may affect the $\mathrm{pH}$ during ripening (Upreti and Metzger 2007), although the $\mathrm{pH}$ at coagulation and draining were not statistically different $(P>0.05)$. A further study on the sugar and mineral content of the cheese may bring more insight on the subject.
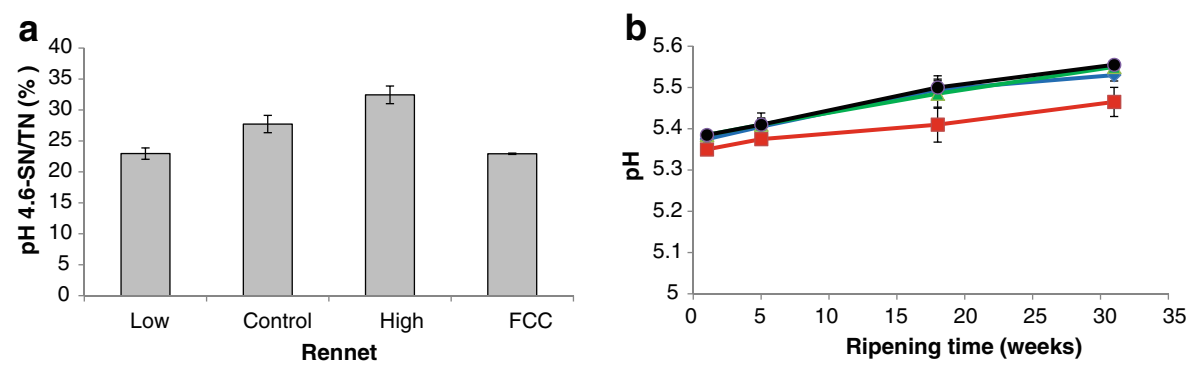

Fig. 5 a The concentration of $\mathrm{pH} 4.6$ soluble nitrogen/total nitrogen ( $\mathrm{pH} 4.6-\mathrm{SN} / \mathrm{TN})$ in cheese at week 31 for cheeses made with different rennet concentrations (low, control or high Hannilase rennet concentration) or different types of rennet (fermentation-produced camel chymosin, FCC). b Changes in the $\mathrm{pH}$ of the cheese made using low (blue diamond), control (red square) or high (green triangle) Hannilase rennet concentration or FCC (black circle) rennet at weeks 1, 5, 18 and 31 of ripening. The results are expressed as the mean \pm the standard deviation of the mean $(n=2)$. Images in colour can be viewed in the electronic version of this manuscript 
Despite a greater retention of rennet, the $\mathrm{pH} 4.6-\mathrm{SN} / \mathrm{TN}$ in the FCC cheese was significantly lower than in the control cheese (Fig. 5a). This can only be explained by the lower general proteolytic activity of FCC (Kappeler et al. 2006). Previous studies have similarly reported lower proteolysis when Cheddar cheese was made with FCC instead of FPC (Bansal et al. 2009; Govindasamy-Lucey et al. 2010) but these results were attributed to a lower strength of FCC rennet; the rennet strengths used in the first study were $\sim 0.039$ IMCU.g $^{-1}$ of milk) of FCC and $~ 0.058$ IMCU.g $^{-1}$ of milk of calf chymosin and in the second study 0.039 IMCU.g $^{-1}$ of milk of FCC and 0.0485 IMCU.g $^{-1}$ of milk of calf chymosin respectively. Moynihan et al. (2014), however, also observed lower levels of proteolysis when cheeses were made with FCC added at the same rennet concentration as FPC, consistent with this study. The findings of this study confirm that the proteolytic activity in cheese is reduced even when FCC is used at a similar rennet strength, consistent with reports of the lower proteolytic activity of the isolated enzyme.

The proteolysis within each of the cheeses was also monitored using SDS-PAGE (Fig. 6a). The proteolytic pattern of Cheddar cheese made with FCC and bovine chymosin produced by fermentation has been compared previously using urea-PAGE
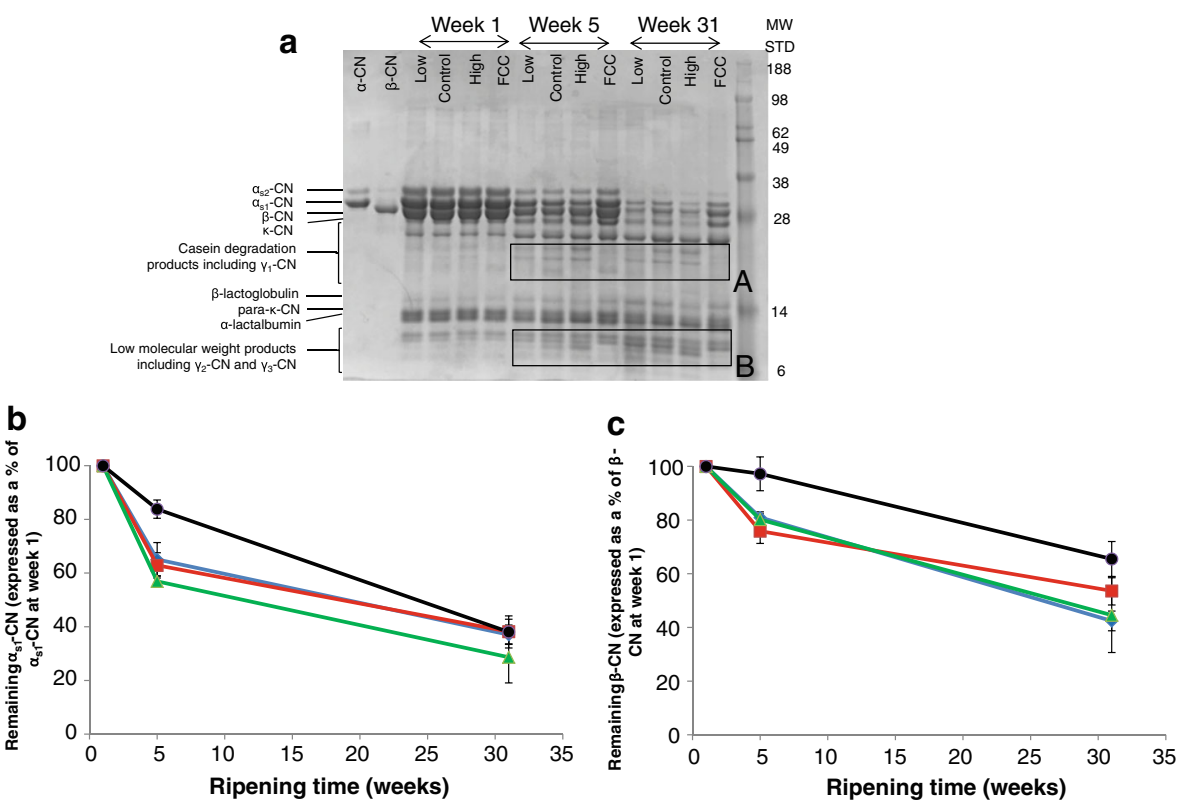

Fig. 6 a Image of SDS-PAGE gel (12\%) of ripened cheeses made using low, control or high rennet Hannilase concentration or fermentation-produced camel chymosin rennet at week 1, week 5 or week 31 of cheese maturation. STD is the standard molecular weight marker and $\alpha-\mathrm{CN}$ and $\beta-\mathrm{CN}$ are pure standards of these compounds. The various protein bands have been identified based on their relative positions on the SDSPAGE gel, with reference to literature (Basch et al. 1989). The black rectangles indicate two regions of interest, named region $\mathrm{A}$ or region $\mathrm{B}$. Changes in the proportion of (b) $\alpha_{\mathrm{s} 1}-\mathrm{CN}$ and (c) $\beta-\mathrm{CN}$, expressed as a percentage of the concentration present in the cheeses at week 1, for cheeses made with low (blue diamond), control (red square) or high (green triangle) Hannilase rennet concentration or fermentation-produced camel chymosin (black circle) rennet. Protein concentration was measured using the intensity of the $\alpha_{\mathrm{s} 1}-\mathrm{CN}$ and $\beta$ $\mathrm{CN}$ protein bands from the SDS-PAGE gel in Fig. 5, at weeks 1, 5 and 31. The results are expressed as the mean \pm the standard deviation of the mean $(n=2)$. Images in colour can be viewed in the electronic version of this manuscript 
(Bansal et al. 2009); however, Fig. 6a reports a comparison of Hannilase and FCC rennet using SDS-PAGE. Protein bands were identified by comparison with $\alpha-\mathrm{CN}$ and $\beta-\mathrm{CN}$ standards, as well as molecular weight standards.

Hydrolysis of $\alpha-\mathrm{CN}$ and $\beta-\mathrm{CN}$ can clearly be observed during ripening as the intensity of the bands decreases between week 1, 5 and 31 for all treatments (Fig. 6a). The breakdown of $\alpha_{\mathrm{s} 1}-\mathrm{CN}$ and $\beta-\mathrm{CN}$, with respect to week 1 , was further quantified (Fig. $6 \mathrm{~b}, \mathrm{c}$ ) and the percentage of $\alpha_{\mathrm{s} 1}-\mathrm{CN}$ and $\beta-\mathrm{CN}$ left was statistically similar for the three Hannilase treatments at both weeks 5 and 31 . This result was somewhat surprising. Differences were apparent, however, in the concentration of casein degradation products, as shown in Fig. 6a. These differences are consistent with differences in the ratio of $\mathrm{pH} 4.6$ soluble nitrogen/total nitrogen ( $\mathrm{pH} 4.6-\mathrm{SN} / \mathrm{TN})$, which measures the $\mathrm{pH} 4.6$ soluble fraction affected by proteolysis.

The protein bands in region marked A $\left(\sim 17-24 \mathrm{~kg} \cdot \mathrm{mol}^{-1}\right)$, for weeks 5 and 31, appear fainter in the cheese made from low rennet concentration compared to cheeses made from control or high concentrations. These regions include the products from the degradation of $\alpha_{\mathrm{s} 1}-\mathrm{CN}, \alpha_{\mathrm{s} 2}-\mathrm{CN}$ and $\beta-\mathrm{CN}$ (Basch et al. 1989), which could indicate proteolytic differences as a result of different rennet concentrations. Proteolytic products can also be generated by plasmin or can be used by bacteria within the cheese, so these patterns could also reflect different rates of metabolism in the cheese.

The FCC cheeses had significantly higher residual $\alpha_{\mathrm{s} 1}-\mathrm{CN}$ and $\beta-\mathrm{CN}$ at week 5 compared to the control cheese (Fig. 6b, c), which can be attributed to slower proteolysis in these cheeses. The data collected at week 31 , however, suggest that the type of rennet does not significantly affect the degradation of $\alpha_{\mathrm{s} 1}-\mathrm{CN}$ and $\beta-\mathrm{CN}$ if the cheeses are given sufficient time to ripen. Previously, the literature has reported both slower initial proteolysis and less final degradation of $\alpha_{\mathrm{s} 1}-\mathrm{CN}$ in Cheddar cheeses made with FCC, with respect to those made from FPC (Bansal et al. 2009; Børsting et al. 2012). The difference between the results obtained here and previous studies may be due to differences in FCC concentration, as the previous studies used a lower rennet concentration (discussed above).

The proteolytic pattern for cheese made from FCC observed here was overall similar to the pattern for the cheeses made from microbial rennet (Fig. 6a), except for a few distinct differences. Comparing the control cheese and the cheese from FCC at weeks 5 and 31, it can be seen that FCC has less intense protein bands in the region marked A and has only two protein bands in the region marked B (molecular weight in range of $\sim 8-12 \mathrm{~kg}^{-\mathrm{mol}^{-1}}$ ) instead of the three observed for the control cheese. These protein bands most likely belong to proteolytic products from $\alpha-\mathrm{CN}$ and $\beta-\mathrm{CN}$. Such differences in proteolytic specificity and total proteolytic activity can affect levels of bitterness or 'brothy' characteristics and also alter the availability of precursors for other flavour compounds.

\subsection{Texture profile during ripening}

The cheese hardness was significantly affected by time, as assessed by the texture analysis $(P<0.05$, Fig. 7). The rennet concentration, however, did not significantly affect cheese hardness. Moynihan et al. (2014) also showed that low-moisture partskim Mozzarella cheese made with high concentrations of bovine chymosin had higher 


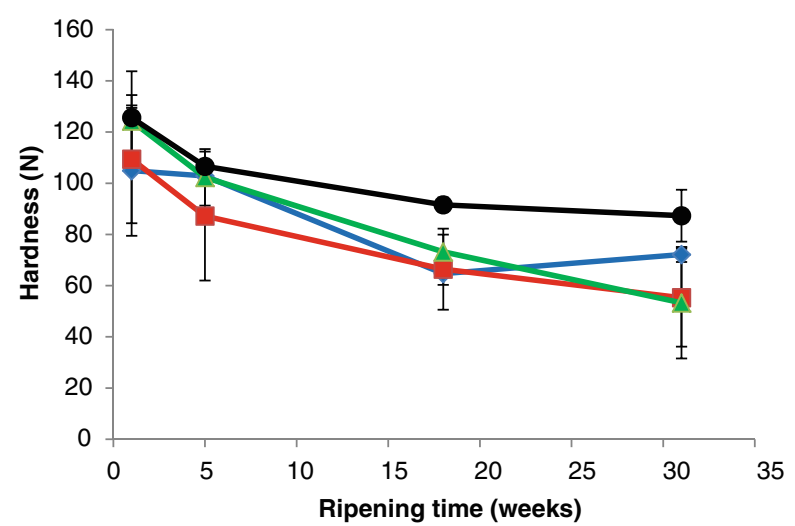

Fig. 7 Changes in the hardness of cheeses made using low (blue diamond), control (red square) or high (green triangle) Hannilase rennet concentration or fermentation-produced camel chymosin (black circle) rennet at weeks $1,5,18$ and 31 of ripening. The results are expressed as the mean \pm the standard deviation of the mean $(n=2)$ (Colour figure online)

proteolysis after 28 days, as indicated by $\mathrm{pH} 4.6$ soluble nitrogen, than the cheese made with low concentrations of bovine chymosin. In the same study, however, it was also observed that the hardness of cheeses made with high and low bovine chymosin did not differ significantly during ripening. This suggests that the hardness may not be determined solely by proteolysis and may be affected by other factors such as calcium phosphate solubilisation (O'Mahony et al. 2005).

The FCC cheeses were slightly harder than the cheeses made with Hannilase at weeks 18 and 31 (Fig. 7). The difference in hardness between rennet treatments was not significant $(P>0.05)$ when analysed independently of time. Multiple linear regression of the combined data at weeks 18 and 31, however, showed that the rennet type significantly affected the texture $(P<0.05)$. This result parallels previous studies that found that cheeses made with FCC were significantly harder than cheese made with FPC (Bansal et al. 2009; Govindasamy-Lucey et al. 2010). When Mozzarella cheese was made with different concentrations of recombinant chymosin $\left(0.06-0.1 \mathrm{~mL} \cdot \mathrm{kg}^{-1}\right.$ of milk), the texture was not significantly different (Kindstedt et al. 1995), similar to the results shown with Hannilase here. These studies illustrate that the three enzymes from calf, camel and microbial sources behave differently and may differ in their influence on texture during ripening.

\section{Conclusion}

Reduced fat Cheddar cheese was produced using different concentrations of microbial rennet as well as an alternative enzyme, recombinant camel chymosin. Increasing the concentration of rennet or using a different rennet type (Hannilase versus FCC) altered the milk coagulation time but did not affect the overall processing time. The composition and yield of the cheese were similar, as was the loss of protein and fat to the whey.

The rennet concentration affected the gel microstructure, which was more porous qualitatively when a high concentration of rennet was used. The residual rennet in the 
cheese increased when the amount of rennet was increased from low to medium concentrations, as expected. Increasing the rennet concentration used above the control value, however, yielded cheeses with a statistically similar amount of residual rennet to the control. These results show that most of the rennet was lost to the whey when high concentrations were employed, which may have been accentuated by the increased porosity of the gel at higher rennet levels. The residual rennet in the cheese was significantly higher in the cheeses made from camel chymosin compared to Hannilase, despite the similar rennet strength used in both treatments. At the end of the observed ripening period, the microstructure of the cheeses as shown by cryo-SEM was different, with a thicker protein network observed for the cheese made with recombinant camel chymosin, which may be indicative of the slower proteolysis shown by this cheese during ripening.

The results of this study suggest that at high concentrations of Hannilase rennet, most of the rennet was lost to the whey and the cheese was not significantly texturally different. Conversely, the use of a lower concentration of rennet resulted in slower initial proteolysis but the texture was not significantly affected, suggesting that manufacturers could adopt lower concentrations of rennet. The recombinant camel chymosin could also potentially be used as a substitute for Hannilase, especially for products that require a lower degree of proteolysis.

Acknowledgments The authors acknowledge the Australian Government for providing the Australian Postgraduate Award (APA) scholarship and Dairy Innovation Australia for financial support (08209C). We thank Murray Goulburn, Lion and Warrnambool Cheese and Butter for their involvement in the project. We also thank the Particulate Fluids Processing Centre (PFPC), the Bio21 Institute, the Electron Microscopy Unit and the Biological Optical Microscopy Platform for equipment access and Mr Roger Curtain for his help in operating the cryo-SEM.

Conflict of interest Kevany Soodam, Lydia Ong, Ian B. Powell, Sandra E. Kentish and Sally L. Gras declare that they have no conflict of interest.

\section{References}

Atwood CS, Hartmann PE (1992) Collection of fore and hind milk from the sow and the changes in milk composition during suckling. J Dairy Res 59(03):287-298

Australian Standard (1990) Methods of chemical and physical testing for the dairying industry - Cheese Determination of salt. Australian Standard AS 2300.6.5

Australian Standard (1991) Methods of chemical and physical testing for the dairying industry - General methods and principles - Determination of nitrogen - Reference Kjeldahl method Australian Standard AS 2300.1.2.1

Australian Standard (2008) Methods of chemical and physical testing for the dairying industry - General methods and principles - Determination of fat - Gravimetric method. Australian Standard AS 2300.1.3

Bansal N, Drake MA, Piraino P, Broe ML, Harboe M, Fox PF, McSweeney PLH (2009) Suitability of recombinant camel (Camelus dromedarius) chymosin as a coagulant for Cheddar cheese. Int Dairy J 19(9):510-517

Basch JJ, Farrell HM Jr, Walsh RA, Konstance RP, Kumosinski TF (1989) Development of a quantitative model for enzyme-catalyzed, time-dependent changes in protein composition of Cheddar cheese during storage. J Dairy Sci 72(3):591-603

Berg JM, Tymoczko JL, Stryer L (2007) Appendix B: acidity constants. In: Biochemistry 6th edn. WH Freeman and Company, New York

Børsting MW, Qvist KB, Rasmussen M, Vindeløv J, Vogensen FK, Ardö Y (2012) Impact of selected coagulants and starters on primary proteolysis and amino acid release related to bitterness and structure of reduced-fat Cheddar cheese. Dairy Sci Technol 92(5):593-612 
Børsting MW, Qvist KB, Ardö Y (2014) Influence of pH on retention of camel chymosin in curd. Int Dairy J 38(2):133-135

Creamer LK, Iyer M, Lelievre J (1987) Effect of various levels of rennet addition on characteristics of Cheddar cheese made from ultrafiltered milk. N Z J Dairy Sci Technol 22(3):205-214

de Jong L (1977) Protein breakdown in soft cheese and its relation to consistency. II. The influence of the rennet concentration. Neth Milk Dairy J 31(4):314-327

Dulley JR (1974) The contribution of rennet and starter enzymes to proteolysis in cheese. Aust J Dairy Technol 29(2):65-69

Fenelon MA, Guinee TP (1999) The effect of milk fat on Cheddar cheese yield and its prediction, using modifications of the Van Slyke cheese yield formula. J Dairy Sci 82(11):2287-2299

Fenelon MA, Guinee TP (2000) Primary proteolysis and textural changes during ripening in Cheddar cheeses manufactured to different fat contents. Int Dairy J 10(3):151-158

Govindasamy-Lucey S, Lu Y, Jaeggi JJ, Johnson ME, Lucey JA (2010) Impact of camel chymosin on the texture and sensory properties of low-fat Cheddar cheese. Aust J Dairy Technol 65(3):139-142

Green ML, Turvey A, Hobbs DG (1981) Development of structure and texture in Cheddar cheese. J Dairy Res 48(02):343-355

Holmes DG, Duersch JW, Ernstrom CA (1977) Distribution of milk clotting enzymes between curd and whey and their survival during Cheddar cheese making. J Dairy Sci 60(6):862-869

Hurley MJ, O'Driscoll BM, Kelly AL, McSweeney PLH (1999) Novel assay for the determination of residual coagulant activity in cheese. Int Dairy J 9(8):553-558

Kappeler SR, van den Brink HM, Rahbek-Nielsen H, Farah Z, Puhan Z, Hansen EB, Johansen E (2006) Characterization of recombinant camel chymosin reveals superior properties for the coagulation of bovine and camel milk. Biochem Biophys Res Commun 342(2):647-654

Kindstedt PS, Yun JJ, Barbano DM, Larose KL (1995) Mozzarella cheese: impact of coagulant concentration on chemical composition, proteolysis, and functional properties. J Dairy Sci 78(12):2591-2597

Kumar A, Grover S, Sharma J, Batish VK (2010) Chymosin and other milk coagulants: sources and biotechnological interventions. Crit Rev Biotechnol 30(4):243-258

Martin P, Raymond MN, Bricas E, Dumas BR (1980) Kinetic studies on the action of Mucor pusillus, Mucor miehei acid proteases and chymosins $\mathrm{A}$ and $\mathrm{B}$ on a synthetic chromophoric hexapeptide. Biochim Biophys Acta Enzymol 612(2):410-420

Moore DS (1985) Amino acid and peptide net charges: a simple calculational procedure. Biochem Educ 13(1): $10-11$

Moynihan AC, Govindasamy-Lucey S, Jaeggi JJ, Johnson ME, Lucey JA, McSweeney PLH (2014) Effect of camel chymosin on the texture, functionality, and sensory properties of low-moisture, part-skim Mozzarella cheese. J Dairy Sci 97(1):85-96

O'Keeffe AM, Fox PF, Daly C (1978) Proteolysis in Cheddar cheese: role of coagulant and starter bacteria. J Dairy Res 45(03):465-477

O'Mahony JA, Lucey JA, McSweeney PLH (2005) Chymosin-mediated proteolysis, calcium solubilization, and texture development during the ripening of Cheddar cheese. J Dairy Sci 88(9):3101-3114

Ong L, Henriksson A, Shah NP (2006) Development of probiotic Cheddar cheese containing Lactobacillus acidophilus, Lb. casei, Lb. paracasei and Bifidobacterium spp. and the influence of these bacteria on proteolytic patterns and production of organic acid. Int Dairy J 16(5):446-456

Ong L, Dagastine RR, Kentish SE, Gras SL (2011) Microstructure of milk gel and cheese curd observed using cryo scanning electron microscopy and confocal microscopy. LWT Food Sci Technol 44(5):1291-1302

Ong L, Dagastine RR, Kentish SE, Gras SL (2012) The effect of pH at renneting on the microstructure, composition and texture of Cheddar cheese. Food Res Int 48(1):119-130

Ong L, Dagastine R, Kentish S, Gras S (2013) Microstructure and composition of full fat Cheddar cheese made with ultrafiltered milk retentate. Foods 2(3):310-331

Ong L, Soodam K, Kentish SE, Powell IB, Gras SL (2015) The addition of calcium chloride in combination with a lower draining $\mathrm{pH}$ to change the microstructure and improve fat retention in Cheddar cheese. Int Dairy J 46:53-62

Pesce MA, Strande CS (1973) A new micromethod for determination of protein in cerebrospinal fluid and urine. Clin Chem 19(11):1265-1267

Sheehan JJ, O'Sullivan K, Guinee TP (2004) Effect of coagulant type and storage temperature on the functionality of reduced-fat Mozzarella cheese. Lait 84(6):551-566

Soodam K, Ong L, Kentish SE, Powell IB, Gras SL (2014) The effect of milk protein concentration on the microstructure and textural properties of full fat Cheddar cheese during ripening. Food Bioprocess Technol 7(10):2912-2922 
Soodam K, Ong L, Powell IB, Kentish SE, Gras SL (2015) Effect of calcium chloride addition and draining $\mathrm{pH}$ on the microstructure and texture of full fat Cheddar cheese during ripening. Food Chem 181:111-118

Sousa MJ, McSweeney PLH (2001) Studies on the ripening of Cooleeney, an Irish farmhouse Camemberttype cheese. Irish J Agric Food Res 40(1):83-95

Sousa MJ, Ardö Y, McSweeney PLH (2001) Advances in the study of proteolysis during cheese ripening. Int Dairy J 11(4-7):327-345

Spangler PL, Jensen LA, Amundson CH, Olson NF, Hill CG Jr (1991) Ultrafiltered Gouda cheese: effects of preacidification, diafiltration, rennet and starter concentration, and time to cut. J Dairy Sci 74(9):28092819

Stanley DW, Emmons DB (1977) Cheddar cheese made with bovine pepsin II. Texture-microstructurecomposition relationships. Can Inst Food Sci Technol J 10(2):78-84

Upreti P, Metzger LE (2007) Influence of calcium and phosphorus, lactose, and salt-to-moisture ratio on Cheddar cheese quality: $\mathrm{pH}$ changes during ripening. J Dairy Sci 90(1):1-12

Ustunol Z, Hicks CL (1990) Effect of milk-clotting enzymes on cheese yield. J Dairy Sci 73(1):8-16

Wium H, Pedersen PS, Qvist KB (2003) Effect of coagulation conditions on the microstructure and the large deformation properties of fat-free Feta cheese made from ultrafiltered milk. Food Hydrocoll 17(3):287296 